THURSDAY, JULY I6, I89ז.

\section{ORGANIZERS OF TECHNICAL EDUCATION IN CONFERENCE.}

THE progress that has been made during the past year by English County Councils in the application of their grants under the Local Taxation Act to purposes of technical education is attested by the map which accompanies the fourth Annual Report of the National Association for the Promotion of Technical and Secondary Education, and which we reproduce. It will be seen from this map that the counties which have determined to use the whole of the new fund for education form a large majority of the whole number both in England and Wales; and that London and Middlesex enjoy an unenviable, and we hope temporary, distinction, in having been the only counties to grab for the rates the whole of the money which might have been used to organize the secondary and technical education of their districts.

But while the map and the Report offer sufficient evidence of the good intentions of the County Councils, the solid progress already achieved is still more em. phatically shown by the Conference of organizing secretaries which followed the annual meeting of the Association on the $3^{\text {rd }}$ of this month. The very post of organizing secretary is the creation of the past few months. A year ago no county had dreamt of appointing an official to look after its education, and the Technical Instruction Act was only in operation in a few scattered centres. Now nearly twenty counties and county boroughs have special educational departments, with paid organizing secretaries. We need hardly point out the wisdom of making such appointments, in view of the unwonted duties cast on County Councils by recent legislation. The task is one which needs all the ability which is available, and this ability is of a highly specialized character, not to be expected of the average County Councillor or Clerk of the Peace, who besides have not the time for the necessary detailed work of organization. To leave the work to clerks would be to court failure, for the work to be attempted within the next few years must be largely tentative, and the direction of the experiments must be in the hands of men of knowledge, ideas, and resource, as well as of tact and judgment.

The selection of such men is not easy, and we are glad to find that the secretaries of the Technical Association are prepared to suggest candidates to County Councils which may be in need of them. The appointments made hitherto have been of two kinds : as temporary organizers, to inquire into claims and applications, to visit every district in the county, and to draw up a detailed scheme as the result of such inquiry ; and as permanent secretaries to the Technical Instruction Committees, charged with the work of carrying out the schemes and inspecting the instruction, either personally or through the employment of experts.

About two-thirds of the gentlemen who had been appointed up to the date of the Conference accepted the invitation to be present, the districts represented being Lancashire, Cumberland, Surrey, Sussex, Derbyshire, No. I I 33, vOL. 44]
Devonshire, Oxfordshire, Nottinghamshire, and Hampshire, besides a few county boroughs. The Conference was private and informal, its object being rather the interchange of views and the comparison of notes than the adoption of any formal resolution.

The subject chosen for consideration was the relation of the local taxation grant to secondary schools-the most difficult, as well as the most important, of the questions with which the organizer finds himself face to face when preparing a scheme. Since Matthew Arnold wrote, the disgraceful condition of secondary education in England has been a common-place; but how inefficient many of the schools are, and what tracts of country are entirely without even such facilities as they offer, is probably scarcely realized by any except those who have made a minute study of the educational wants of an average county. The country grammar-school, with small endowment and ill-paid and lethargic head master assisted by a worse paid and more inefficient usher, is all thatstandsfor secondary education in many a market-town. Manyare without even the semblance of a school above the elementary rank, and the mass of the inhabitants, it is to be feared, hardly feel the want of anything more. Here and there an energetic master or governing body has succeeded in building up a good school in despite of local apathy and lack of funds, but the fee has to be pitched at a point which excludes wage-earners, and such schools are consequently "middle," not only in the character of their instruction, but also in the class by which they are attended. Meanwhile, the clever boy of the village national school, who might profit the nation by his brains and energy, is doomed, for lack of opportunity, to leave school at twelve for the hopeless rut of farm labour.

A country-side the general education of which is as here described is not a promising field for special technical instruction. A stupid set of uneducated farmers, and a scarcely less stupid class of uneducated labourers, form hardly a good soil in which to plant lectures on agricultural chemistry or the natural history of insect pests. And thus thoughtful observers have been driven everywhere to the conclusion, no less in country than in town, that access to good secondary schools is an even more crying need at the present day than the specialized instruction to which, indeed, a sound general education is the necessary preliminary.

What, in short, is wanted, is that within reach of every inhabitant of every county should be a good secondary school, with fees such as may be reasonably expected to be paid by small farmers and tradesmen, and to which all sons of artisans and labourers who can pass a reasonable examination before the age of twelve can have access by means of scholarships.

The question before the Conference was the best means of promoting this object under the powers given by the Technical Instruction Acts. It will be remembered that the definition of technical instruction in the Act of 1889 is sufficiently wide to cover most of the subjects taught in a secondary school, and it is therefore clear that aid can be given to such schools, provided that the County Council can be represented on the governing bodies, and that the schools are not conducted for private profit. As regards the erection of new schools, it is doubtful if the whole work of building could be undertaken, even if desired, by 
the County Council, but there is nothing to hinder contributions from being made towards the cost of laboratory, fittings, and apparatus; while a maintenance grant could be given to defray the expense of the teaching of scientific and technical subjects. It was stated at the Conference that the Charity Commissioners had shown every dis- picked scholars from elementary to secondary, and from secondary to higher institutions, was unanimously agreed; and it was further considered that the scholarships to secondary schools should not merely defray the fees, but should provide something towards the cost of maintaining the boy while at school. The advantage of choosing the

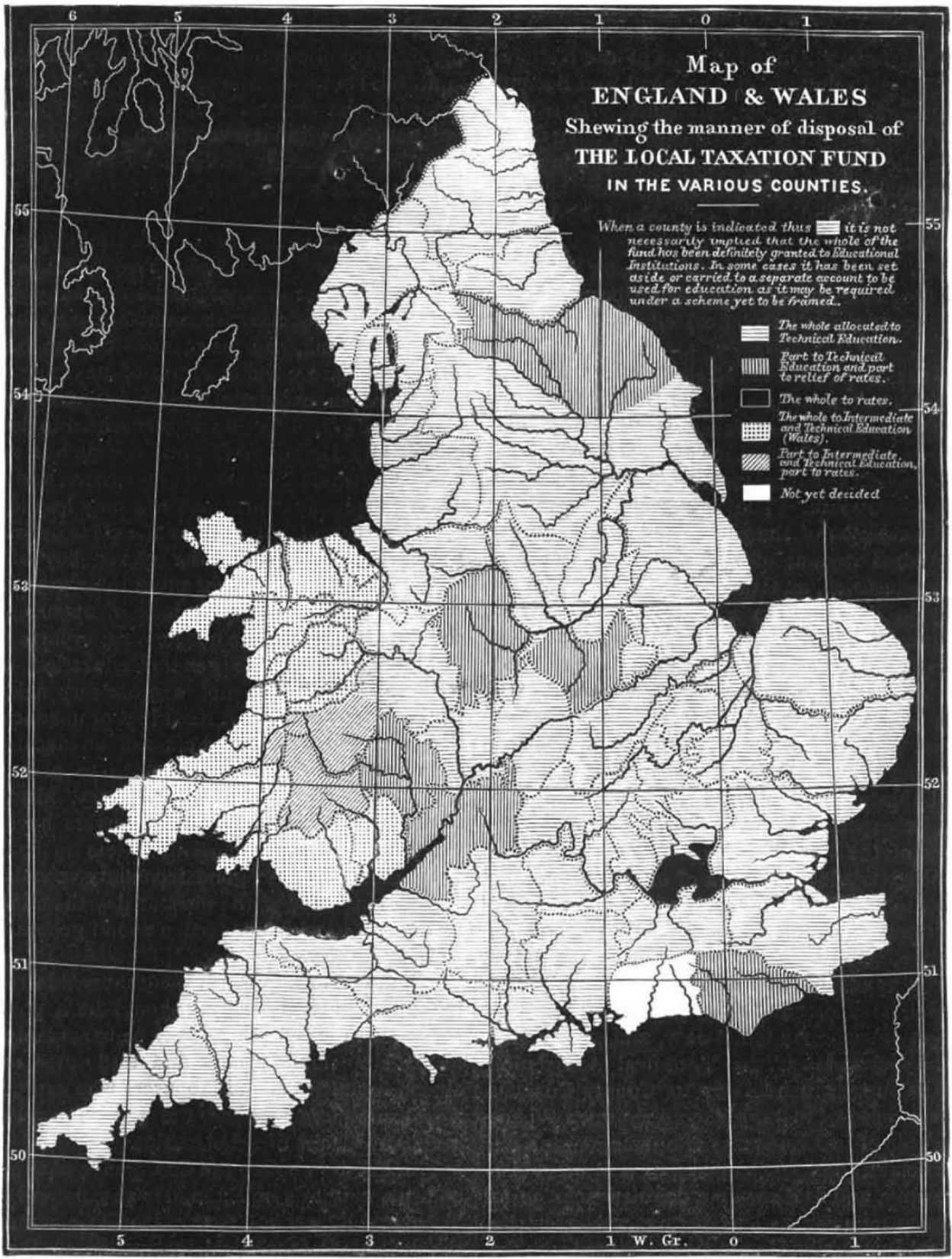

position to facilitate the work, by drafting amending schemes enabling the County Council to be duly represented on the governing bodies.

But the subject which chiefly occupied the attention of the Conference was that of scholarships. That some scheme of scholarships should be devised to carry on scholars as young as possible, in order to give them the full advantage of secondary training, was also insisted upon.

The question whether the selection of scholars, by examination or otherwise, should be undertaken by the County Council, or left to the governing bodies of the

NO. I I 33, VOL. 44] 
secondary schools, or to the discretion of the teachers of the elementary schools, elicited some difference of opinion; but on the whole the Conference favoured the plan of examination by a board appointed by the County Council, acting as far as possible in co-operation with the head masters of the secondary schools of the county. On one point all were agreed: viz. that there should be two examinations, or at least two standards-one for the country districts and the other for the towns-lest the whole of the scholarships should be monopolized by the most favoured districts. The opinion was also expressed that it might be sometimes desirable (as apparently would not be illegal under the Technical Instruction (Amendment) Act, I89I) to make scholarships tenable at certain efficient private profit schools, where no public schools are available, although such schools are debarred from receiving direct assistance. Such a course, however, would have to be adopted with the utmost caution.

Finally, the Conference considered the relations of the County Councils to the Technical Association, and a unanimous opinion was expressed in favour of a closer connection, while a suggestion was thrown out for the establishment of a quarterly journal registering the progress made in the various counties, a proposal which we are glad to hear is receiving the careful consideration of the Association.

Altogether, the discussion was felt to be of considerable value to those who have the practical work of organization in hand. We hope that such a Conference will be held annually, even if not more often, for in the novel work which lies before the County Councils points of difficulty will continually occur, on which consultation will be most useful. By the way, why should not the organizing secretaries form a permanent Association, on the model of the two Associations of Head Masters?

\section{THE EVOLUTION OF ANIMALS.}

L'Évolution des Formes Animales, avant l'Apparition de l'Homme. By F. Priem. 384 pages. Illustrated. (Paris: Baillière et Fils, r89r.)

$\mathrm{N}$ this addition to the series of volumes known as the "Bibliothèque Scientifique Contemporaine," we have a worthy companion to Prof. Gaudry's "Les Ancêtres de Nos Animaux," published three years ago. To some extent, indeed, the ground is covered by M. Gaudry's more ambitious "Les Enchaînements du Monde Animal," but since the latter is in three volumes, the present work ought to find numerous readers who might be repelled by the length of the other. Moreover, the work before us has the advantage of treating each group of animals throughout geological time in consecutive form, whereas in the "Enchaînements" the Palæozoic Invertebrates are described in one volume, and those of the Secondary period in another, while the Tertiary forms are not recorded at all. Again, our author enters much more fully into the probable origin of one group from another than is the case in Gaudry's work. It is true, indeed, that in most cases these views are not original ; but since they are generally taken from the highest authorities on the several groups, they will commend themselves the more strongly to students. In most works on palæontology NO. I I 33, VOL. 44] too little attention is, in our opinion, generally given to the evolution of the various groups of the Invertebrata from one another, and we can, therefore, give a hearty welcome to a volume like the present which is mainly devoted to this fascinating subject.

We need hardly say that Prof. Priem is an out-and-out evolutionist; and we trust that we shall not disparage his work by observing that in some cases-apparently carried away by the very natural desire to make the most of his subject-he appears to have gone rather too far, stating as facts what are at best but probable hypotheses. For instance, we find it definitely stated on p. 273 that the Stegocephalous (Labyrinthodont) Amphibians had a functional parietal eye, whereas there is, of course, no actual proof that this was the case.

The work is rendered attractive by the large number of woodcuts with which it is illustrated. We regret, however, that in some cases-and more especially among the Vertebrates-the execution of these figures is by no means satisfactory. Moreover, in the chapters devoted to the Vertebrates (some of which are the weakest portions of the work) there are figures which are not only bad, but are utterly untrue to nature. Thus on p. 266 the old figure of Coccosteus, with the maxillary bone doing duty for the mandible, once more reappears; while on p. 30 I we have the reproduction of Goldfuss's erroneous restoration of Pterodactylus crassirostris, which is unfortunately given as an illustration of the short-tailed genus Pterodactylus, whereas that particular species belongs to the long-tailed genus Scaphognathus.

We notice that in many instances $M$. Priem gives his authority for his statements as to the phylogeny of particular groups, whereas in other cases such references are omitted. This is to be regretted, since it is often somewhat difficult to find out whether the author is promulgating his own views, or quoting those of others.

The volume commences with an introductory chapter on palæontological evolution, in which the phylogeny of the horse, and the well-known passage of Paludina neumayri into $P$. harnesi are instanced as the best examples we have of the derivation of one form from another. Following this chapter, we have the various groups of animals treated in detail, commencing from the lowest. In the main the classification adopted is fairly well up to date, although we shall note some instances where the author departs from the more usual modern arrangements.

For example, in treating of the classification of the Sponges on p. 36 , the author disregards Prof. Sollas's separation of the Calcareous Sponges (Calcispongiæ) as a group of equal value with all the others (Plethospongiæ), so that we find the Soft, Horny, Flinty, and Calcareous Sponges ranked as equivalent groups. Again, in the Cœlenterate: (or, as we prefer to call them, Zoophytes), the Palæozoic Corals are still classed under the primary divisions of Tabulata and Rugosa; the former group including such different forms as Favosites (belonging to the Zoantharia) and Heliolites, Halysites and Chatetes (usually referred to the Alcyonaria). Later on, however, pp. 62-64, the author recognizes Heliolites and its allies as the ancestors of the modern coral-like Alcyonarians, such as the Organ-pipe Coral (Tubipora), and we there- 